\title{
Correlation of Leaf Glucose Content with Mineral Nutrients Uptake of South African Geranium (Pelargonium Sidoides)
}

\author{
Kinyua J. K. ${ }^{1}{ }^{*}$, Kinyanjui T. ${ }^{2}$, Gachanja A. N. ${ }^{3}$, Maina Jedidah M. ${ }^{4}$ \\ ${ }^{1}$ Kenya Agricultural Research institute, KARI Kabete. P.O. Box 14733-00800, Nairobi, Kenya \\ ${ }^{2}$ Egerton University, Department of Chemistry. P.O. Box 536, Njoro, Kenya. \\ ${ }^{3}$ Jomo Kenyatta University of Science \& Technology, Department of Chemistry. P.O. Box 62000 Nairobi, Kenya. \\ ${ }^{4}$ Eastern Africa Agricultural Productivity Project (EAAPP), P.O. Box 30028-00100 Nairobi, Kenya
}

\begin{abstract}
The relationships between soil nutrients uptake, leaf glucose contents, and chlorophyll contents of Pelargonium sidoides was investigated. Pelargonium sidoides is a medicinal plant grown in Kenya for export. It is used in the manufacture of drugs for lung related diseases. $P$. sidoides plants were selected at a field site, where the soil N, P, K and Ca contents had prior been analysed. These plants were dressed with both inorganic (Calcium Ammonium Nitrate, Triple Super Phosphate, Calcium Carbonate, Potassium Nitrate) and organic fertilizers (worm leachate) of known nutrient levels. Leaf glucose contents before and after application of the mineral nutrients were measured by colorimetry. Verification of the colorimetric results was done by high performance liquid chromatography fitted with a refractive index detector (HPLC). Predictions for nutrients in soil and plant tissues were done by DRIFT FTIR. Leaf chlorophyll measurements were done by Soil Plant Analysis Development units (SPAD). The mean glucose contents before and after each nutrients application were subjected to GENSTAT statistical software for the ANOVA and $t$-test to find out whether there were any significant differences between the two. The results indicated that the levels of leaf glucose increased with type and uptake of certain applied fertilizers. FTIR predictions closely matched the wet chemistry data. Uptake of calcium corresponded to the highest increase of glucose while that of worm leachate had the least effect. Change in glucose levels was evident within an hour after application, suggesting the possibility of predicting nutrients uptake within a short period. Chlorophyll content was also found to increase with nutrients uptake. All plants treated with fertilizers displayed significantly higher glucose contents in comparison to the control samples. The study opened way for real time analysis of plant status and allowed for real time interventions where necessary.
\end{abstract}

Key words: nutrients uptake, leaf glucose content, chlorophyll content, organic and inorganic fertilizers

\section{Introduction}

The uptake of most plant mineral nutrients from the soil has the effect of altering leaf glucose content during photosynthesis. Leaf glucose synthesis during photosynthesis is strongly correlated to the uptake of mineral nutrients (Marschner, 1995, Britto and Kronzucker, 2008). Carbon dioxide consumption in the leaf has been reported to be affected by changes in concentration of nitrate, phosphate, and potassium ions as well as intensity of radiation applied for plants like cotton and tomatoes (Claussen et al., 2006). High production level of glucose in plants is an indication of efficient utilization of photosynthetic processes (Rengel, 1999). The photosynthesis process involves energy photons, adenosine triphosphate (ATP), reduced nicotinamide adenine dinucleotide phosphate (NADPH) and electron transfer systems. Mineral nutrients influence photosynthetic electron flow in various ways, either as constituents of the light-harvesting complex or as ions facilitating electron flow (Rengel, 1999). Ultimately, mineral nutrients available to the plant will have a strong effect on photosynthesis and how they are utilized in the plant sink organs or storage sites.

Pelargonium sidoides (Umckaloabo, South African Geranium) is a medicinal plant native to South Africa. $P$. sidoides grows in the wild in South Africa with some being cultivated as cash crop. It grows in short grasslands and sometimes with occasional shrubs and trees on stony soil varying from sand to clay-loam, altitudes ranging from near sea level to $2300 \mathrm{~m}$ (http://www.plantzafrica.com/plantnop/pelargsidoid.htm). It grows in areas which receive rainfall varying from 200-280mm per annum (http://www.plantzafrica.com/plantnop/pelargsidoid.htm).

Root extracts from $P$. sidoides is used for treatment of respiratory tract medical conditions such as acute bronchitis (Matthys et al., 2003, Chuchalin et al., 2005), acute non-Group A Beta Hemolytic Streptococcus (nonGABH) tonsillopharyngitis (sore throat) and the common cold (Bereznoy et al., 2003, Lizogub et al., 2007). Chemical analysis of root extracts of $P$. sidoides has led to characterization of about 65 metabolites including phenolic and cinnamic acids, tannins, flavonoids glycosides and coumarins (Kolodziej, 2000, Seidel and Taylor 
2004, Kayer and Tan 2002). Schnitzer et al. (2008) analyzed the compounds of aqueous root extract of $P$. sidoides by LC-MS and found it to be comprised predominantly of coumarins, simple phenolic structures as well as flavonoid and catechin derivatives. The broad spectrum of activity against viruses and bacteria may be caused by the coumarins and phenolic acids (Kolodziej, 2007).

The health of $P$. Sidoides is controlled by appropriate soil minerals uptake and glucose concentration in the leaves. This concentration is governed by soil nutrients concentration and plant uptake capacity. The nutrients are normally applied as commercial inorganic and organic fertilizers. The quality of the root tuber extracts (the useful portion of the plant), determines its commercial value. Application of unnecessary and excessive fertilizers for $P$. sidoides production, leads to wastage of financial resources, and endangers the environment. There is need to establish the relationship between soil macro/micronutrient concentrations, plant mineral nutrient uptake, the quality of root tubers and glucose and chlorophyll contents in healthy plants which is not known. The objective of this study was to determine the effect of mineral nutrient application to selected $P$. sidoides plants on the levels of leaf glucose and chlorophyll content. Determination of the appropriate fertilizers and uptake ability will help growers to minimize fertilizer wastage, protects environment, and improve crop quality.

\subsection{General objective}

Determine the correlation between leaf glucose and chlorophyll contents with uptake of inorganic and organic fertilizers on $P$. sidoides.

\subsection{Specific objectives}

(a) To determine available $\mathrm{N}, \mathrm{P}, \mathrm{K}$ and $\mathrm{Ca}$ in the soil in the experimental plot before application of recommended inorganic and organic fertilizers using both wet chemistry and FTIR.

(b) To determine the available amount of N, P, K and Ca in organic fertilizer (worm juice).

(c) To determine leaf glucose and chlorophyll contents on $P$. sidoides leaves before and after application of inorganic and organic fertilizers.

(d) To determine $\mathrm{Ca}, \mathrm{N}, \mathrm{P}, \mathrm{K}, \mathrm{Mg}, \mathrm{Mn}$, and $\mathrm{OC}$ contents in the leaves $P$. sidoides before and after application of inorganic and organic fertilizers.

\section{Materials And Methods}

A portion of a large commercial plantation of $P$. sidoides plants, located in Laikipia West district, Kenya, $\left(0.41^{0}\right.$ North, $36.6^{0}$ East $)$ was used for experimental trials. The study site was a $25 \mathrm{~m} \mathrm{x} 40 \mathrm{~m}$ plot of land containing 30 rows of $P$. sidoides plants and 160 plants per row. The site was divided into 10 blocks of three rows containing 480 plants per block. Each block then was divided into four portions of 120 plants each. Three of these portions were treated as treatment replicates 1,2, and 3 while the fourth one was left out as a control. This was repeated for each of the ten treatments as shown on Table 1.

Worm juice was prepared by sprinkling water on top of large worm biodegradation tanks and the leachate collected through drainage taps at the bottom of the tanks. The leachate was then poured into a 200 litres tank, aerated with an air pump for 48 hours, to increase an aerobic (oxygenated) environment for enhanced microorganisms' activities. The resultant product from the biodegradation tanks was applied as an organic fertilizer on the plants (Worm Juice (WJ)). Five grammes of each fertilizer (inorganic N, P, K, Mg, Ca) and worm juice (ratio 1:1 WJ/water) was applied to each plant in the randomized blocks as shown in Table 1. This setup was a randomized block design (RBD) for statistical experiments (Clewer, et al., 2001).

Table 1: Fertilizers treatment blocks and replicates details - WJ - worm juice

\begin{tabular}{|l|l|l|c|}
\hline $\begin{array}{c}\text { Block } \\
\text { No. }\end{array}$ & \multicolumn{1}{|c|}{ Plot Name } & \multicolumn{1}{|c|}{ Treatment } & $\begin{array}{c}\text { No. of Reps } \\
\text { + Control }\end{array}$ \\
\hline 1 & Worm Juice (WJ) & $1: 1 \mathrm{v} / \mathrm{v}$ Worm Leachate $:$ Water & 4 \\
\hline 2 & Calcium Ammonium Nitrate (CAN) & Nitrogen Fertilizer & 4 \\
\hline 3 & Triple Super Phosphate (TSP) & Phosphate Fertilizer $(0: 40: 0+3 \mathrm{~S})$ & 4 \\
\hline 4 & Potassium Nitrate $\left(\mathrm{KNO}_{3}\right)$ & Potassium Fertilizer $(13: 0: 46)$ & 4 \\
\hline 5 & Calcium Carbonate $\left(\mathrm{CaCO}_{3}\right.$ & Calcium Fertilizer $(26: 0: 0+20 \mathrm{Ca})$ & 4 \\
\hline 6 & WJ+CAN & $1: 1 \% \mathrm{v}$ Worm Juice $:$ Water + N Fertilizer & 4 \\
\hline 7 & WJ+TSP & $1: 1 \mathrm{v} / \mathrm{v}$ Worm Juice $:$ Water + P Fertilizer & 4 \\
\hline 8 & WJ+KNO & 4 \\
\hline 9 & WJ+CaCO3 & $1: 1 \%$ Worm Juice $:$ Water + K Fertilizer & 4 \\
\hline 10 & WJ+CAN+TSP+KNO & $+\mathrm{CaCO}_{3}$ \\
\hline
\end{tabular}




\subsection{Sampling}

Soil samples from (taken with an auger to a depth of $60 \mathrm{~cm}$ ) six sampling locations randomly selected in the experimental site. Three adjacent holes were sampled from each location. The soil was mixed well to form a composite sample, and then the final $1 \mathrm{~kg}$ sample was taken. A total of six samples were taken in triplicates for analysis.

Leaves for glucose analysis, were randomly sampled in a cross-sectional pattern from the top of the plant, picking 10 leaves per plant. A total of 40 plants were randomly selected along the rows. The samples were then combined to form three composite samples for each treatment. Sampling was carried out at intervals of 1, 2, 3, 6, 12, 24 hours, 2 weeks and 12 weeks ( 3 months) later. Untreated plants were used as control samples.

\subsection{Chlorophyll and leaf glucose analysis}

The plants were twenty eight weeks old when the study began. Each treatment block was divided into three sub-blocks. Two of these sub-blocks were treated with fertilizer while the third was left out as a control. Six plants were randomly selected from each sub-block. Six young fully expanded leaves were randomly selected on each plant for chlorophyll measurements using Soil Plant Analysis Development units (SPAD). Triplicate readings were taken; on one side of the midrib of each single leaf blade, midway between the leaf base and tip and then averaged. The average for each treatment sub-block was taken to represent the chlorophyll contents for each treatment. There were ten treatments $(\mathrm{N}=10)$ whose chlorophyll content means, were treated to a two samples t-test. A SPAD meter (model number 502 from Spectrum Technologies) was used. Chlorophyll measurements were first carried out two weeks after application of fertilizers and once again 12 weeks (3months) later. The analytical method as outlined by Miller, (1979) was used for analysis of leaf glucose.

\subsection{Soil analysis}

Mid Infrared (MIR) spectra for the soil samples were done using an ALPHA ${ }^{\text {TM }}$ Fourier Transform Infrared (FTIR) spectrometer (Bruker Optics, Billerica, MA, USA) equipped with DRIFT (diffuse reflectance infrared Fourier Transform) sampling modules. OPUS 6.0 (Optical User Software) was used to convert spectrums to spc files (spectroscopic data files) so that they could be subjected to ' $\mathrm{R}$ ' statistical software.

Mehlich double acid extraction method was used to extract soil samples (Mehlich, 1953). This was followed by analysis of phosphorous by colorimetric measurement of the colour intensity of vanadomolybdophosphoric acid formed on addition of ammonium vanadate-molybdate mixture to the soil extract. Calcium, sodium, and potassium were determined by flame photometry while Flame Atomic Absorption spectrometry was used for determination of magnesium and manganese. Total organic carbon was determined by colorimetric method as outlined in Anderson and Ingram, (1993). Determination of Total Nitrogen was determined by Kjeldahl method as outlined in Hinga, et al.,(1980). Measurement of $\mathrm{pH}$ was by 1:2.5 soil/water suspensions as outlined in Anderson and Ingram, (1993).

\subsection{Data analysis}

Analysis of variance (ANOVA) was done for the leaf glucose content data obtained to compare the amount of leaf glucose before and after nutrients application. Two samples t-test was used to for the analysis of chlorophyll data and HPLC versus DNS analytical methods. Statistical computer programs used to analyse the data, included Genstat, MS excel and 'R' statistical software (Mervik and Wehrens, 2007).

\subsection{Results for analysis of mineral nutrients in the soil samples \\ III. Results And Discussions}

Results obtained from analysis showed that the soil was deficient in most of the essential nutrients (phosphorous and nitrogen) while a few were higher than recommended levels (manganese, magnesium and potassium). The results obtained by wet chemistry were verified using values obtained from the FTIR predictions. The soil $\mathrm{pH}$ ranged between 7.00 and 7.13, which was neutral and suitable for most crops growth (Weast 1981). The soil analytical results also showed that calcium was within adequately needed contents, with values ranging within 10 and 12 meq per $100 \mathrm{~g}$ of soil against recommended values of $2.0-15 \mathrm{meq} / 100 \mathrm{~g}$ of soil. Manganese values ranged between 1.49 and 2.85 meq \% against a recommendation range of 0.11 to 2.0 meq per $100 \mathrm{~g}$ of soil while magnesium was between 3.49 and 8.54 meq per $100 \mathrm{~g}$ of soil against recommended ranges of between 1.0 and $3.0 \mathrm{meq} / 100 \mathrm{~g}$ of soil for magnesium. Potassium was slightly in excess (above upper limit of $1.50 \mathrm{meq} / 100 \mathrm{~g}$ of soil, while 
phosphorous and nitrogen values were lower than recommended ranges of $30-80 \mathrm{ppm}$ and $0.2-0.5 \%$ respectfully (http://www.hill-laboratories.com/file/fileid/45433).

The FTIR predictions were obtained from calibration curves of 108 FTIR spectrums acquired for samples whose wet chemistry data were known. These were results from previous laboratory wet chemistry analysis. Fig. 1 below shows the raw FTIR spectra of the 108 wet chemistry samples which were used for calibration and predictions for the unknowns. Results from the analysis of variance (ANOVA) to correlate the two sets of data, is shown in Table 2.

Table 2: Results from ANOVA for FTIR versus wet chemistry soil analytical data

\begin{tabular}{|c|c|c|c|c|c|c|c|c|c|}
\hline \multirow[b]{3}{*}{ Method } & \multicolumn{8}{|c|}{ Parameters measured } & \\
\hline & \multicolumn{5}{|c|}{ Meq\% } & \multicolumn{2}{|c|}{$\%$} & \multirow{2}{*}{$\begin{array}{l}\mathrm{ppm} \\
\mathbf{P}\end{array}$} & \\
\hline & $\mathrm{Ca}$ & $\mathbf{K}$ & Mg & Mn & $\mathbf{N a}$ & $\mathbf{N}$ & OC & & pH \\
\hline Fourier TIR (Mean N=6) & 12.01 & 2.28 & 5.57 & 2.26 & 0.40 & 0.16 & 1.38 & 22.03 & 7.09 \\
\hline Wet Chemistry (Mean N=6) & 11.92 & 2.41 & 4.97 & 2.15 & 0.40 & 0.09 & 1.43 & 22.26 & 7.06 \\
\hline$\alpha$-value & 0.05 & 0.05 & 0.05 & 0.05 & 0.05 & 0.05 & 0.05 & 0.05 & 0.05 \\
\hline Calculated p-value & 0.746 & 0.326 & 0.173 & 0.528 & 0.950 & $<0.01$ & 0.621 & 0.667 & 0.041 \\
\hline Differences in the two methods & ns & ns & ns & $\mathrm{ns}$ & $\mathrm{ns}$ & $\mathrm{s}$ & ns & $\mathrm{ns}$ & $\mathrm{s}$ \\
\hline
\end{tabular}

ns $=$ no significant difference in results obtained by the two methods-(calculated $p$-value $>\alpha$-value)

$\mathrm{s}=$ there is a significant difference in results obtained from the two methods- (calculated $p$-value $<\alpha$-value

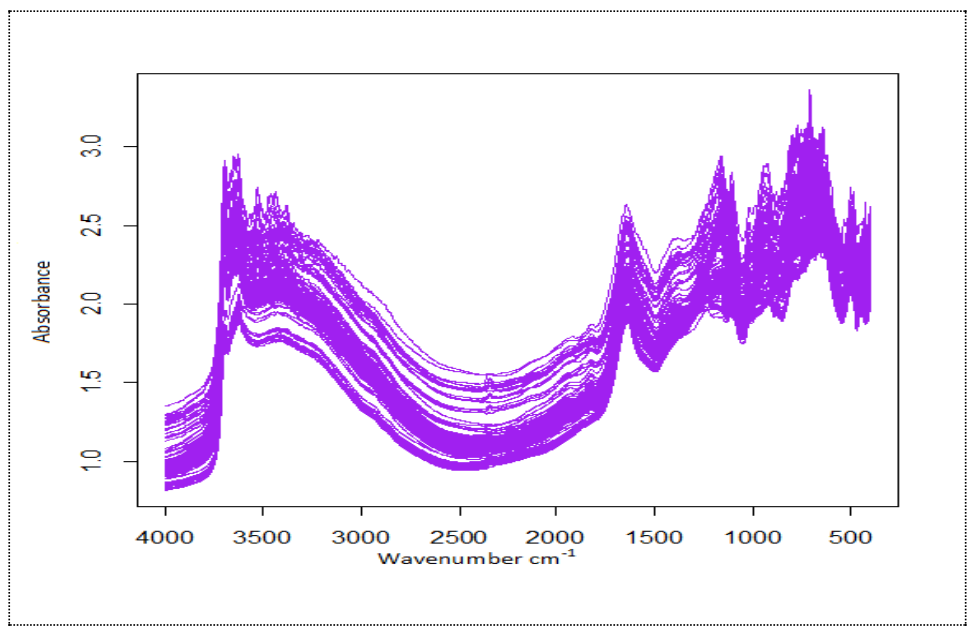

Figure 1: FTIR Spectrums overlays for wet chemistry samples used for calibration.

From the statistical data on Table 2 above, wet chemistry and FTIR soil analytical data had no significant difference except for nitrogen and $\mathrm{pH}$ values. Low values of nitrogen obtained through wet chemistry analysis may have been as a result of loss of nitrogen during sample digestion. Soil analysis by FTIR requires minimal sample preparation; involves non-destructive process (Puckrin et, al., 1996). Though the $\mathrm{pH}$ values from the two methods are statistically significantly different, both showed neutral $\mathrm{pH}$ values of around 7 .

The results from the analysis of worm juice for mineral nutrient $(\mathrm{N}, \mathrm{P}, \mathrm{K}, \mathrm{Ca}, \mathrm{Mg}$ and $\mathrm{Mn}$ ) contents are shown on Table 3. The worm juice (1:1 water mixture) was rich in phosphorus at $273 \mathrm{mg} / \mathrm{l}$, calcium at $124 \mathrm{mg} / \mathrm{l}$ while nitrogen was below detection limit $(0.01 \mathrm{mg} / \mathrm{l})$. This was equivalent to NPK (N 0, P27.3, K0.21 percent) fertilizer which was very low in both nitrogen and potassium. 
Table 3: Results for the analysis of mineral nutrients concentrations in worm juice

\begin{tabular}{|l|l|c|}
\hline WORM JUICE & \multicolumn{2}{|c|}{ Concentration } \\
\hline Parameter tested & $(\mathrm{mg} / \mathrm{l})$ & \\
& \multicolumn{2}{|c|}{} \\
\hline Nitrogen & $<0.1$ & 27.3 \\
\hline Phosphorous & 273 & 0.21 \\
\hline Potassium & 2.10 & 12.4 \\
\hline Calcium & 124 & 9.84 \\
\hline Magnesium & 98.4 & 0.37 \\
\hline Manganese & 3.71 & \\
\hline
\end{tabular}

\subsection{Effect of fertilizer applications on leaf glucose content}

The variation in leaf glucose content with time (ranging from $1 \mathrm{~h}$ to 12 weeks or 3 months) for different fertilizer applications is shown in Fig. 2. The glucose contents for all untreated (control) plants in the study area had significantly the same quantity of glucose. They also displayed the least changes in glucose contents throughout the time of study. The highest changes in the mean glucose contents observed for an individual treatment, were those obtained after application of Calcium Carbonate based lime fertilizer. Lime fertilizer displayed the highest amount of increase within the first hour's sampling at $2.50 \mathrm{mg} / \mathrm{g}$ of glucose. Application of mixtures of $\mathrm{CaCO}_{3}$ and worm juice $\left(\mathrm{CaCO}_{3}+\right.$ worm juice) yielded the highest changes in glucose content, one hour after the application of the mixture. On the other hand, application of mixtures of Triple Super Phosphate and Worm Juice yielded the most significant changes in mean glucose contents during the duration of this study.

The lowest increase in glucose levels was observed at $0.77 \mathrm{mg} / \mathrm{g}$ for worm juice. It was however, noted that all applications yielded an increase in glucose levels. In all the treatments, the levels of glucose increased some within the first hour and decreased gradually with time except in the cases of potassium and worm juice where the highest increase was observed within the first six hours. The highest levels of glucose were observed within six hours after application of nutrients.

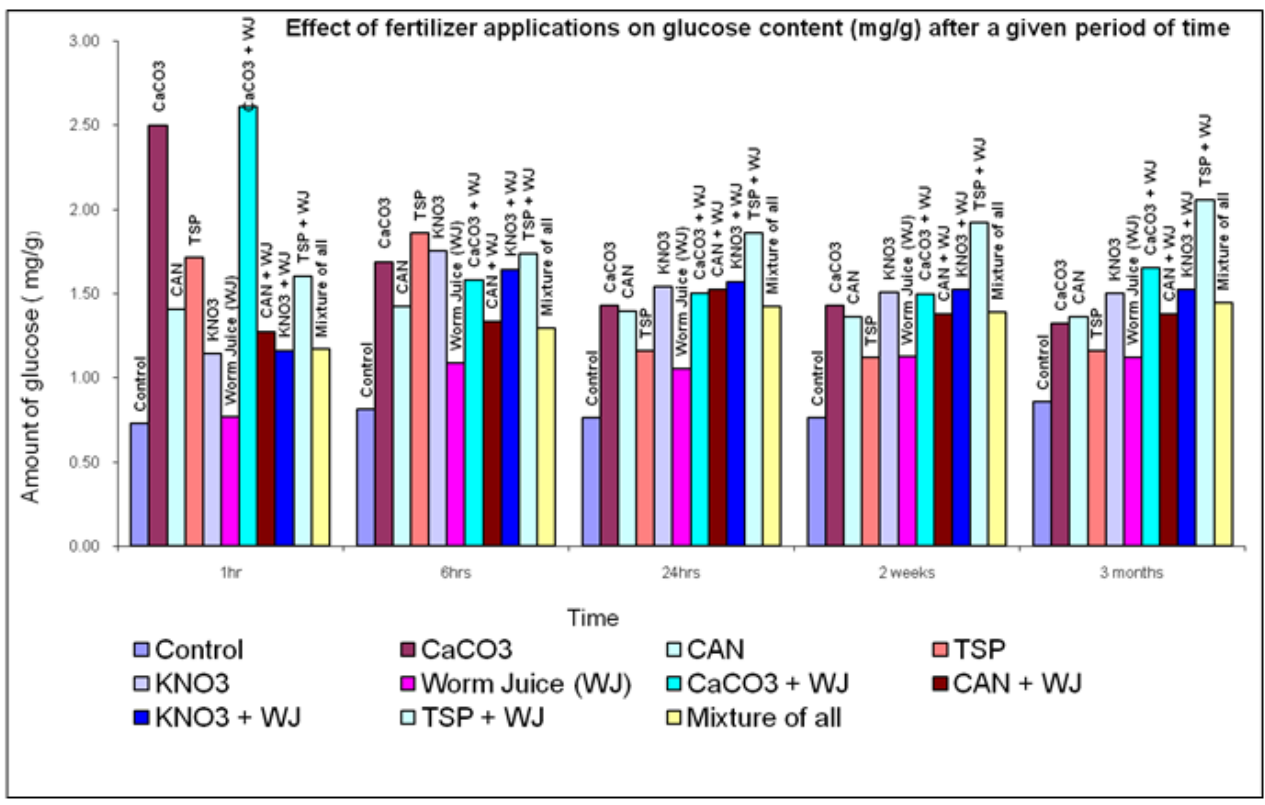

Figure 2: Changes in glucose contents for all fertilizer applications over time

There was a significant difference between initial and final glucose for each application $(p<0.001)$ indicating that leaf glucose contents increased in the plants that were treated with fertilizers (Table4). 
Table 4: Analysis of variance (variate = glucose content)

\begin{tabular}{|l|l|l|l|l|l|}
\hline Source of variation & d.f. & S.s. & m.s. & F & pr. \\
\hline Time & 4 & 0.391776 & 0.097944 & 19.01 & $<.001$ \\
\hline Application & 19 & 88.406948 & 4.652997 & 903.16 & $<.001$ \\
\hline Time vis Application & 76 & 18.32022 & 0.241056 & 46.79 & $<.001$ \\
\hline Residual & 500 & 2.575953 & 0.005152 & & \\
\hline Total & 599 & 109.694896 & & & \\
\hline Stratum standard errors and coefficients of variation & \multicolumn{1}{l|}{} \\
\hline d.f. & s.e. (standard deviation) & cv\% \\
\hline 500 & 0.07178 & 6.3 & \\
\hline
\end{tabular}

Where;

$\alpha=1-\%$ confidence level $(1-0.95=0.05)$

d.f. $=$ degrees of freedom

$\mathrm{F}=\mathrm{F}$ Value $-\mathrm{F}$ statistic associated with the given source.

$\mathrm{Pr}=\mathrm{p}$ value associated with the $\mathrm{F}$ statistic of a given source

s.s.= sum of squares

m.s. $=$ mean squares

$\mathrm{cv} \%=$ coefficients of variation

s.e. $=$ standard error of the means (Standard deviation)

(probability)

\subsection{Effect of nutrients uptake on leaf chlorophyll levels}

Fig. 3 below shows the changes in chlorophyll contents (SPAD units) two weeks and three months after application of fertilizers. Statistical analysis for chlorophyll data is shown on Table 5.

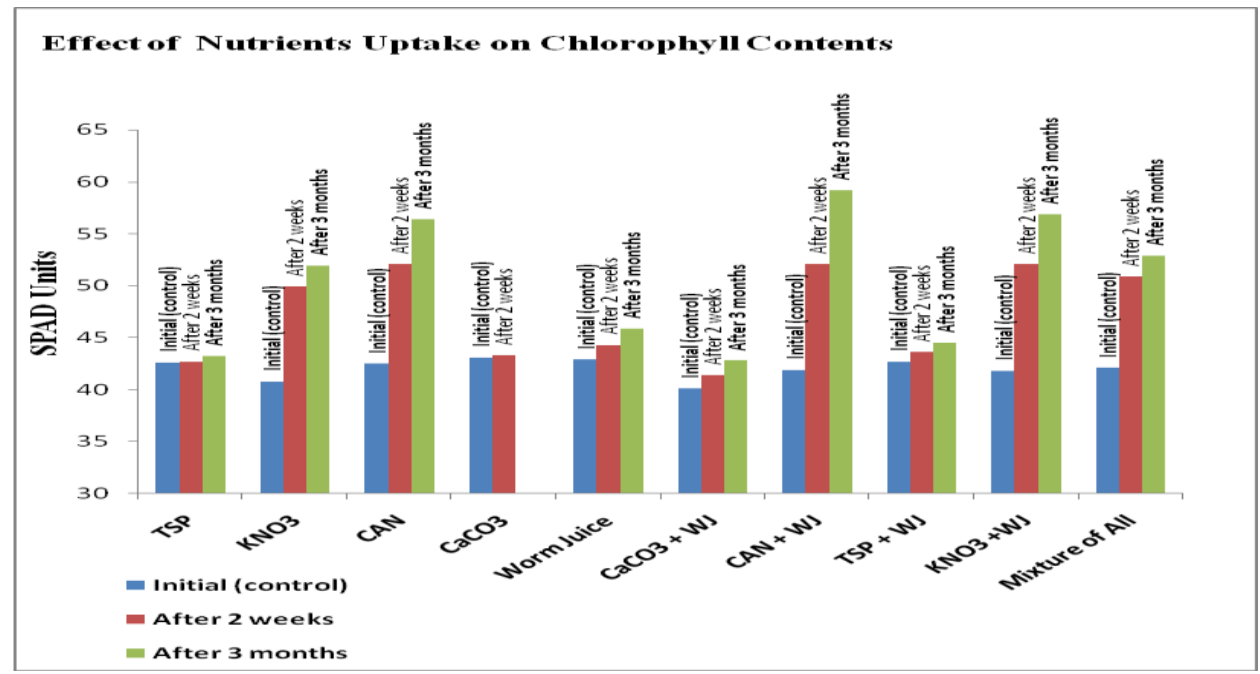

Figure 3: Effect of nutrients application on leaf chlorophyll content

Table 5: t-test for the changes in leaf chlorophyll three months after applications

\begin{tabular}{|l|l|l|l|l|l|}
\hline Sample & $\begin{array}{l}\text { Size } \\
(\mathbf{N})\end{array}$ & Mean & Variance & Standard Deviation & Standard error of mean \\
\hline Initial (SPAD units) & 10 & 42.05 & 0.91 & 0.955 & 0.302 \\
\hline After 3 months(SPAD) & 10 & 51.39 & 30.65 & 5.537 & 1.751 \\
\hline
\end{tabular}

\section{Difference of means}

Standard error of difference

$95 \%$ confidence interval for difference in means

t-value $(\alpha=0.05,9$ d.f. $)$

Test statistic t

\section{$-9.340$}

1.777

$(-13.33,-5.355)$

$\mathbf{1 . 8 3 3}$

5.26

The probability was $<0.001$ at $95 \%$ level of confidence that the initial and 3 months SPAD values were the statistically the same. Hence there was a significant difference between chlorophyll contents before fertilizers application and the contents three months later. The changes in the levels of chlorophyll were more pronounced on applications of nitrogen based fertilizers. The highest percentage increase on chlorophyll contents were observed 
after an application of calcium ammonium nitrate $(\mathrm{CAN})$ and potassium nitrate $\left(\mathrm{KNO}_{3}\right)$, and were higher where the two were mixed with worm juice (WJ). There was a very close link between chlorophyll and nitrogen content as other investigators have reported (Evans, 1983, Field and Moony, 1986, Amaliotis et al., 2004). This is understandable because, nitrogen is a structural element of chlorophyll and protein molecules, and therefore affects formation of chloroplasts and accumulation of chlorophyll in them (Tucker, 2004, Daughtry et al., 2000). Application of triple super phosphate fertilizer (TSP) also had an effect on chlorophyll levels. Calcium carbonate $\left(\mathrm{CaCO}_{3}\right)$ had the least observed variations. Application of a mixture of all fertilizers under study i.e., CAN, TSP, $\mathrm{KNO}_{3} \mathrm{CaCO}_{3}$ and $\mathrm{WJ}$ had less changes in chlorophyll than expected (fig. 3).

\subsection{FTIR predictions of leaf nutrients using pre-determined wet chemistry data.}

Leaf nutrients were analysed for mineral nutrient contents before and three months after application of fertilizers. Analysis was done by FTIR using predictions based on plant tissue samples' wet chemistry data. Calibration data used were results from previous wet chemistry plant tissues analysis. The results were compared with data from the interpretive values table for Geranium (Pelargonium) (Reuter and Robinson, 1986). The leaf nutrients were found to be below the recommended levels for $\mathrm{N}, \mathrm{P}$ and $\mathrm{K}$ but higher for Ca while $\mathrm{Mg}$ and $\mathrm{Mn}$ were sufficient. The results shown in fig. 6 gives the comparison between the recommended plant nutrient ranges with the values obtained from analytical tests.

Fig. 4 shows the spectrum overlays for the plant tissue wet chemistry, used for FTIR calibrations and production of the nutrients prediction data. The results for the analysis were then subjected to statistical analysis for comparison of leaf nutrients before and after application fertilizers.

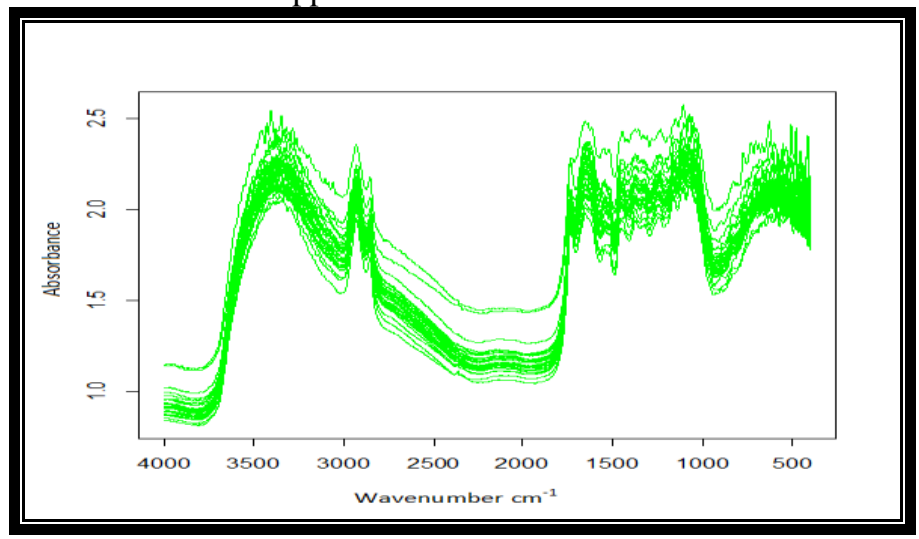

Figure 4: FTIR Spectrums overlays for plant wet chemistry samples used for calibration

A two sample t-test was used to compare the differences in mineral contents in the leaves before and three months after application (Table 6). Results revealed that there was significant difference in some individual nutrients for the treatments. These results indicate a significant increase in leaf calcium after application of $\mathrm{CaCO}$ and $\mathrm{CAN}$ fertilizers $(\mathrm{P}=<0.001$ at $95 \%$ confidence interval). Equally, nitrogen increased significantly three months after application of CAN fertilizers $(\mathrm{P}=0.04)$. There were significant differences in changes of Phosphorus three months after addition of TSP $(\mathrm{P}=<0.001)$ and worm juice fertilizers $(\mathrm{P}=0.02)$. The significant difference in increase of Phosphorus in the leaves after only worm juice was applied may be attributed to the high concentration of $\mathrm{P}$ in the worm juice. 
Correlation Of Leaf Glucose Content With Mineral Nutrients Uptake Of South African .....

Table 6: t-test for the changes in leaf nutrients 3 months after application of fertilizers

\begin{tabular}{|c|c|c|c|c|c|c|c|c|c|}
\hline \multirow[t]{2}{*}{ Treatment } & \multirow[t]{2}{*}{ Time } & \multicolumn{6}{|c|}{$\%$} & \multicolumn{2}{|c|}{ ppm } \\
\hline & & $\mathbf{C a}$ & $\mathbf{K}$ & Mg & $\mathbf{N a}$ & $\mathbf{N}$ & $\mathrm{P}$ & $\mathbf{F e}$ & Mn \\
\hline \multirow{2}{*}{$\mathrm{CaCO}_{3}$} & Before (mean) & 1.26 & 1.23 & 0.41 & 59.82 & 2.22 & 017 & 742.3 & 60.4 \\
\hline & After (mean) & 2.00 & 1.58 & 0.41 & 59.90 & 2.19 & 0.19 & 613.7 & 49.3 \\
\hline p-value & & $<0.001$ & 0.108 & 0.935 & 0.995 & 0.641 & 0.519 & 0.509 & 0.348 \\
\hline \multirow[b]{2}{*}{ CAN } & Before (mean) & 1.14 & 1.16 & 0.67 & 45.53 & 2.15 & 0.22 & 596.3 & 67.2 \\
\hline & After (mean) & 1.673 & 1.32 & 0.39 & 48.37 & 2.50 & 0.20 & 609.0 & 56.3 \\
\hline p-value & & $<0.001$ & 0.336 & 0.009 & 0.888 & 0.044 & 0.386 & 0.888 & 0.116 \\
\hline \multirow[b]{2}{*}{ TSP } & Before (mean) & 1.23 & 1.52 & 0.40 & 48.85 & 2.05 & 1.18 & 813.7 & 66.43 \\
\hline & After (mean) & 1.23 & 1.34 & 0.51 & 51.11 & 2.18 & 1.38 & 689.0 & 60.67 \\
\hline p-value & & 0.840 & 0.540 & 0.242 & 0.862 & 0.536 & 0.001 & 0.092 & 0.343 \\
\hline \multirow[b]{2}{*}{$\mathrm{KNO}_{3}$} & Before (mean) & 1.31 & 1.23 & 0.39 & 49.67 & 2.29 & 0.197 & 705.3 & 58.97 \\
\hline & After (mean) & 1.29 & 1.41 & 0.61 & 48.67 & 2.48 & 0.163 & 938.3 & 71.97 \\
\hline p-value & & 0.633 & 0.210 & 0.125 & 0.956 & 0.208 & 0.152 & 0.020 & 0.056 \\
\hline \multirow[b]{2}{*}{$\mathbf{W j}$} & Before (mean) & 1.25 & 1.23 & 0.53 & 48.67 & 2.24 & 0.18 & 659.0 & 63.4 \\
\hline & After (mean) & 1.27 & 1.23 & 0.54 & 48.73 & 2.18 & 0.21 & 695.7 & 60.5 \\
\hline p-value & & 0.189 & 0.927 & 0.798 & 0.981 & 0.304 & 0.018 & 0.988 & 0.646 \\
\hline
\end{tabular}

\section{Conclusion}

The soil was low in $\mathrm{N}$ and $\mathrm{P}$, but sufficient with $\mathrm{Ca}$ and high in $\mathrm{K}$ levels (compared to the optimum levels shown in Soil interpretative values table, (Horneck et, al,. 2011). However, the glucose increases were observed for $\mathrm{Ca}$ and $\mathrm{P}$ applications more than in others. Calcium forms insoluble compounds with other elements in soil, such as phosphorous and is not available to plants (Bruce et al., 1989). Calcium-phosphorous precipitation occurs when free calcium accumulates in the soil solution forming insoluble compounds with phosphorous. Consequently, phosphorous availability is also significantly decreased (Brady and Weil, 2002). Therefore application of these two nutrients into the soil may have increased the availabilities of $\mathrm{Ca}$ and $\mathrm{P}$ (in readily plant absorbable form) and hence an increase in glucose levels. Low soil Ca may have been as result of the presence of competing ions. Calcium competes with other positively charged ions, such as sodium $\left(\mathrm{Na}^{+}\right)$, potassium $\left(\mathrm{K}^{+}\right)$, and magnesium $\left(\mathrm{Mg}^{+2}\right)$ which in this case were found to be high in the soil therefore was not available to the plants.

There exists a strong interaction between $\mathrm{N}$ and $\mathrm{K}$ where a crop must also have access to, and take up, an adequate amount of potassium from the plant-available (exchangeable K) pool of K in the soil (Johnston and Milford, 2012). For that reason, glucose levels for $\mathrm{KNO}_{3}$ treatments increased with time and then stabilized. This could have been attributed to the low $\mathrm{K}$ levels found in the plant tissues analysis although there was more than sufficient $\mathrm{K}$ content in the soil.

The slow mobility of phosphorous in the first, sixth and twenty fourth hours after application of fertilizers, was attributed to the fact that phosphorous, is only slightly soluble in the soil and enters the plant by diffusion. Psorption occurs when the orthophosphates, $\mathrm{H}_{2} \mathrm{PO}_{4}{ }^{-}$and $\mathrm{HPO}_{4}{ }^{2-}$, bind tightly to soil particles (Scachtman et al., 1998). The solubility of phosphate minerals is very dependent upon soil $\mathrm{pH}$. The soil $\mathrm{pH}$ for optimum phosphorus availability is 6.5 (Brady and Weil, 2002). At higher or neutral pH, phosphate reacts with calcium to form minerals, such as apatite (hydroxylapatite, fluorapatite and chlorapatite). The $\mathrm{pH}$ of this soil was neutral which could have led to low $\mathrm{P}$ availability.

Glucose increases were observed on the application of $\mathrm{CAN}$ and $\mathrm{KNO}_{3}$ fertilizers. Plants can take up $\mathrm{N}$ in the ammonium $\left(\mathrm{NH}_{4}^{+}\right)$or nitrate $\left(\mathrm{NO}_{3}{ }^{-}\right)$form (Schwoerbel and Tillmanns 1977). At $\mathrm{pH}$ values near neutral ( $\left.\mathrm{pH} 7\right)$, the microbial conversion of $\mathrm{NH}_{4}{ }^{+}$to nitrate (nitrification) is rapid, and crops generally take up nitrate (Brown, D. H. 1982). This was observed by the evidence of an increase in the chlorophyll levels in the leaves. Verification of glucose contents analysis by reduction of 3,5-dinitrosalicylic acid to 3- amino, 5-nitrosalicyclic acid by the free carbonyl group in the glucose molecule, with the HPLC Refractive Index method, showed that the two results were comparable. Worm juice had the least effect on glucose levels due to absence of or very low mineral nutrients except for P. Worm juice had a high P content of $273 \mathrm{mg} / \mathrm{l}$.

Initial soil analytical results, showed that soil $\mathrm{N}, \mathrm{P}, \mathrm{K}, \mathrm{Ca}, \mathrm{Mg}$, and $\mathrm{Mn}$ at the study site, ranged between adequate and low values with others being higher than recommended. Soil calcium appeared to be adequately available, but carbon and nitrogen were lower while magnesium and manganese were found to be slightly higher than recommended. Though soil calcium appeared adequate, it showed only partial availability to the plant. There exist a strong calcium-phosphate bond $\left[\mathrm{Ca}_{3}\left(\mathrm{PO}_{4}\right)_{2}\right]$ formed between soil calcium ions $\left(\mathrm{Ca}^{2+}\right)$ and 
orthophosphates $\left(\mathrm{PO}_{4}{ }^{3-}\right)$. There was a significant increase in leaf glucose levels after application of calcium based fertilizers. This was despite soil test results indicating adequate availabilities of calcium in the soil. The effective increase in glucose levels after calcium based fertilizers application may be attributed to initial lack of plant available calcium in the soil.

Application of worm juice alone had little effect on glucose contents. The juice contained low levels in most nutrients but rich in phosphorous with nitrogen being undetected. It was however observed, that glucose levels increased when worm juice was applied alongside inorganic fertilizers especially $\mathrm{CaCO}_{3}$.

The results showed a correlation between soil mineral nutrients uptakes and leaf glucose level in the $P$. sidoides. Changes in glucose contents were observable as fast as within an hour after fertilizer application as observed in the $\mathrm{CaCO}_{3}$ and worm juice mixture.

Correlations were also observed between leaf chlorophyll and nitrogen fertilizers application. The amount of chlorophyll (SPAD units) increased significantly three months after application of CAN and $\mathrm{KNO}_{3}$ fertilizers.

Leaf tissue samples analysed for nutrients before and three months after application of fertilizers, showed an increase in mineral nutrients. Calcium increased in the leaves where $\mathrm{CaCO}_{3}$ and $\mathrm{CAN}$ were applied with notable increase in leaf nitrogen in cases of CAN and $\mathrm{KNO}_{3}$ applications. There was observable increases in $\mathrm{P}$ were TSP and worm juice were applied.

FTIR, being fast and requiring minimal sample preparation and practically none use of chemical reagents, is a useful means of analysis. The method was found useful for soil and plant tissue nutrients analysis. Equipped with an FTIR spectrometer, wet chemistry analysis need only be employed for calibration and confirmation purposes where doubtful results are encountered.

\section{Recommendations}

The objective of this study was to determine the effect of mineral nutrient application to selected P. sidoides plants on the levels of leaf glucose and chlorophyll content. Determination of the appropriate fertilizers and uptake ability will help growers to minimize fertilizer wastage, protect environment, and improve crop quality. The results of the study indicated that worm juice alone did not supply the plants with the necessary nutrients. Change in chlorophyll and leaf glucose may be applied as an early indicator of nutrients uptake after fertilizers applications. Further studies ought to be carried out to find out the effect of nutrients uptake on the root glycosides and coumarins (umckalin).

\section{Acknowledgements}

I wish to thank my employer, Kenya Agricultural Research Institute (KARI) and in particular Dr Miano, Assistant Director, KARI and Coordinator, KARI/KASAL project who funded this research work. I also wish to thank Dr Wamwuongo, Assistant Director, KARI, for her constant assistance throughout the project. My special thanks go to my research supervisors for their being readily available and willingness to help when need arouse, not forgetting the management of Chemistry Department, Egerton University, Kenya, for giving me the opportunity to study there for my MSc.

\section{References}

[1]. Amaliotis D., Therios I. and Karatissiou M. (2004). Effect of nitrogen fertilization on growth leaf nutrient concentration and photosynthesis in three peach cultivars. ISHS, Acta

[2]. Horticulturae 449: 36-42.

[3]. Anderson J.M. and Ingram J.S.I. (1993). Tropical Soil Biology and Fertility. A handbook of methods. CAB international, Wallingford, Oxon, UK 2: 63-65

[4]. Bereznoy V. V., Riley D. S., Wassmer G. and Heger M. (2003). Efficacy of extract of Pelargonium sidoides in children with acute nongroup A beta-hemolytic streptococcus tonsillopharyngitis: a randomized, double-blind, placebo-controlled trial. Alternative therapies in health and medicine 9: 68-79.

[5]. Brady N.C. and Weil R.R. (2002). The Nature and Properties of Soils. 13th edition. Pearson Education, Inc, New Jersey 267-268.

[6]. Britto D.T. and Kronzucker H.J. 2008. Cellular mechanisms of potassium transport in plants. Physiologia Plantarum 133: 637-650.

[7]. Brown, D. H. 1982. Mineral nutrition. In: Smith, A. J. E. (ed.). Bryophyte Ecology, Chapman \& Hall, London, 383-444.

[8]. Bruce R.C., Warrell L.A., Bell L.C. and Edwards D.G. (1989). Chemical attributes of some Queensland acid soils. Solid and solution phase compositions. Australian Journal of Soil Research 27: 333-51.

[9]. Clewer A.G. and Scarisbrick D. H. (2001) Practical Statistics and Experimental Design for Plant and Crop Science. John Wiley \& Sons. $58-60$.

[10]. Chuchalin A. G., Berman B. and Lehmacher W. (2005). Treatment of acute bronchitis in adults with a Pelargonium sidoides preparation (EPs 7630): a randomized, double-blind, placebo-controlled trial. The Journal of Science and Healing 1: 437-445.

[11]. Claussen W., Bernhard B., Krumbein A. and Lenz F. (2006). Long-term response of tomato plants to changing nutrient concentration in the root environment - the role of proline as an indicator of sensory fruit quality. Plant Science 171: 323-331. 
[12]. Daughtry, C. S. T., Walthall C. I., Kim M. S., Brown de Colstoun E. and Mcmurtrey J. E. (2000). Estimating corn leaf chlorophyll concentration from leaf and canopy reflectance. Remote Sensing Of Environment 74: 229-239.

[13]. Evans J. R. (1983). Nitrogen and photosynthesis in the flag leaf of wheat (Triticum aestivum L.). Plant Physiology 72: 297-302.

[14]. Field C. and Mooney H. A. (1986): The photosynthesis - nitrogen relationship in wild plants. - In: On the economy of plant form (GIVNISH T. J., Ed.). Cambridge, University Press, 25-53.

[15]. Horneck D.A., Sullivan D.M., Owen J.S., and Hart J.M. (2011). Soil Test Interpretation Guide, pp 2-7. Oregon State University, U.S. Department of Agriculture.

[16]. Hinga, G., Muchena, F. N. and Njihia, C. N. (1980). Physical and chemical methods of soil analysis. National Agric. Laboratories, Nairobi. Laboratory manual of Total Nitrogen Analysis 2: 16-15

[17]. http://www.hill-laboratories.com/file/fileid/45433, retrieved on $13^{\text {th }}$ December 2013.

[18]. http://www.plantzafrica.com/plantnop/pelargsidoid.htm, retrieved on $14^{\text {th }}$ December 2013.

[19]. Johnston A. E. and Milford G. F. J. (2012). Potassium and nitrogen interactions in crops. Potash Development Association. Rothamsted Research, Harpenden, Hertfordshire AL5 2JG.

[20]. Kayer O. and Tan N. (2002). Novel coumarin sulphates from Pelargonium sidoides: isolation, structure and synthetic approach. Proceedings of the Phytochemical Society of Europe 47: 59-64

[21]. Kolodziej H. (2000). Traditionally used Pelargonium species: Chemistry and biological activity of umckaloabo extracts and their constituents. Current Topics in Phytochemistry 3: 77-93.

[22]. Kolodziej H. (2007). Fascinating metabolic pools of Pelargonium sidoides and Pelargonium reniforme, traditional and phytomedical sources of the herbal medicine Umckaloabo. Phytomedicine 6: 9-17.

[23]. Lizogub V. G., Riley D. S. and Heger M. (2007). Efficacy of a Pelargonium sidoides preparation in patients with the common cold: a randomized, double blind, placebo-controlled clinical trial. The Journal of Science and Healing 3: 573-584.

[24]. Marschner H. 1995. Mineral nutrition of higher plants, 2nd edn. London: Academic Press

[25]. Matthys H., Eisebitt R., Seith B. and Heger M. (2003). Efficacy and safety of an extract of Pelargonium sidoides (EPs 7630) in adults with acute bronchitis. A randomised, double-blind, placebo-controlled trial. Phytomedicine 4: 7-17.

[26]. Mehlich, A. (1953). Determination of P, Ca, Mg, K, Na, and NH4. North Carolina Soil Test Division (Mimeo 1953).

[27]. Mervik B. H., Wehrens R. (2007). The pls Package: Principal Components and Partial Least Square Regression in R; Journal of Statistical Software 18(2): 1-24

[28]. Miller G. L., (1979). Use of dinitrosalicylic acid reagent for determination of reducing sugar, Analytical. Chemistry 31: 426.

[29]. Puckrin E., Evans W.F.J. and Adamson T.A.B. (1996) Measurement of tropospheric ozone by thermal emission spectroscopy. Atmospheric Environment 30(4): 563-568

[30]. Rengel Z. (1999). Mineral nutrition of crops: fundamental mechanisms and implications. Technology \& Engineering, Food product Press 6: $121-123$

[31]. Reuter D. J. and Robinson J B. (1986). The plant analysis. An interpretation manual. Inkata Press Pty Ltd., Victoria, Australia: 140-141

[32]. Scachtman D. P., Reid R. J. and Ayling S. M. (1998). Phosphorus Uptake by Plants: From Soil to Cell. Plant Physiology 116: 447-453.

[33]. Schnitzer P., Schneider S., Stintzing F.C., Carle R. and Reichling J. (2008) Efficacy of an aqueous Pelargonium sidoides extract against herpes virus. Phytomedicine 9: 734-740.

[34]. Schwoerbel J. and Tillmanns G. C. (1977). Uptake of nitrate from the water and activity of nitrate reductase by Fontinalis antipyretica L. under light and dark conditions. Archives of Hydrobiology (Supplement.) 48: 412-423.

[35]. Seidel V. and Taylor P.W. (2004). In vitro activity of extracts and constituents of Pelargonium against rapidly growing mycobacteria. International Journal of Antimicrobial Agents 23: 613-619.

[36]. Tucker M. (2004). Primary Nutrients and Plant Growth. - In: Essential Plant Nutrients (Scribed, Ed.). North Carolina Department of Agriculturae

[37]. Weast R.C. 1981. Handbook of chemistry and physics. 150-151.CRC Press, Boca Raton, FL. 